\title{
The Roles of ApoC-III on the Metabolism of Triglyceride-Rich Lipoproteins in Humans
}

\author{
Jan Borén ${ }^{1 *}$, Chris J. Packard ${ }^{2}$ and Marja-Riitta Taskinen ${ }^{3}$ \\ ${ }^{1}$ Department of Molecular and Clinical Medicine, University of Gothenburg, Gothenburg, Sweden, ${ }^{2}$ Institute of \\ Cardiovascular and Medical Sciences, University of Glasgow, Glasgow, United Kingdom, ${ }^{3}$ Research Programs Unit, Clinical \\ and Molecular Metabolism, University of Helsinki, Helsinki, Finland
}

OPEN ACCESS

Edited by:

Erwin Dieter Schleicher,

University of Tübingen, Germany

Reviewed by:

Hans Ulrich Häring,

Tübingen University

Hospital, Germany

Jun Liu,

Fudan University, China

*Correspondence:

Jan Borén

jan.boren@wlab.gu.se

Specialty section:

This article was submitted to

Clinical Diabetes,

a section of the journal

Frontiers in Endocrinology

Received: 09 March 2020

Accepted: 16 June 2020

Published: 28 July 2020

Citation:

Borén J, Packard CJ and Taskinen M-R (2020) The Roles of

ApoC-III on the Metabolism of

Triglyceride-Rich Lipoproteins in Humans. Front. Endocrinol. 11:474.

doi: 10.3389/fendo.2020.00474
Cardiovascular disease (CVD) is the leading cause of death globally. It is well-established based on evidence accrued during the last three decades that high plasma concentrations of cholesterol-rich atherogenic lipoproteins are causatively linked to CVD, and that lowering these reduces atherosclerotic cardiovascular events in humans (1-9). Historically, most attention has been on low-density lipoproteins (LDL) since these are the most abundant atherogenic lipoproteins in the circulation, and thus the main carrier of cholesterol into the artery wall. However, with the rise of obesity and insulin resistance in many populations, there is increasing interest in the role of triglyceride-rich lipoproteins (TRLS) and their metabolic remnants, with accumulating evidence showing they too are causatively linked to CVD. Plasma triglyceride, measured either in the fasting or non-fasting state, is a useful index of the abundance of TRLS and recent research into the biology and genetics of triglyceride heritability has provided new insight into the causal relationship of TRLs with CVD. Of the genetic factors known to influence plasma triglyceride levels variation in APOC3 - the gene for apolipoprotein (apo) C-III - has emerged as being particularly important as a regulator of triglyceride transport and a novel therapeutic target to reduce dyslipidaemia and CVD risk (10).

Keywords: apoC-III, triglycerides, lipoproteins, lipids, cardiovascular disease

\section{STRUCTURE AND REGULATION OF APOC-III}

APOC3 is expressed in hepatocytes and, to a lesser extent in enterocytes (11). It encodes apoC-III, a smaller apolipoprotein of 79 amino acid residues (12). In the circulation, apoC-III is mainly present on TRLs and high density lipoprotein (HDL), and to a lesser extent also on LDL particles (13-16). The distribution of apoC-III between these lipoproteins depends on the metabolic status of individuals, varying between the fasting and postprandial state, and between subjects with normal plasma triglyceride levels and those with hypertriglyceridemia (17-20). Despite the fact that apoC-III was discovered more than 50 years ago (21), we still lack a detailed molecular understanding on how it interacts with lipoprotein particles, enzymes, and cell surface receptors $(12,22-24)$. However, the two amphipathic helices, and the aromatic tryptophan residues in the carboxyl-terminal half of apoC-III seem to be important for its ability to interact with TRLs (25). Once synthesized, apoC-III can undergo posttranslational modification on threonine-74 resulting in three different glycoforms; unsialylated apoC- $\mathrm{III}_{0}$, monosialylated apoC-III 1 and disialylated apoC-III 2 (26). The impact of this posttranslational modification has for long been unclear, but recent results indicate that the glycoforms are cleared differently by liver receptors (27). 
The transcription rate of APOC 3 is decreased by insulin $(28,29)$, peroxisome proliferator-activated receptor- $\alpha(\operatorname{PPAR} \alpha)$ (30), and farnesoid X receptor (FXR) (Figure 1) (32). In contrast, glucose stimulates expression of $A P O C 3$ via hepatic nuclear factor-4 (HNF4) and carbohydrate-responsive element binding protein (ChREBP) (41). It has been proposed that glucosemediated regulation of APOC3 expression promotes a shift in the energy source for peripheral tissues from fatty acids released by lipolysis of TRLs to increased utilization of blood glucose (28, $31,41,42)$. APOC3 expression is therefore upregulated in states of insulin resistance (characterized by insulin resistance and hyperglycemia), and recent results demonstrate that glycaemic control is a major determinant of apoC-III secretion rate in vivo (as measured by stable isotope technology) and thus plasma apoC-III levels (43). In these studies it was reported also that apoC-III metabolism is significantly perturbed in subjects with type 2 diabetes; the apoC-III secretion rate was markedly higher than that seen in BMI-matched non-diabetic controls. Improved glycaemic control with the glucagon-like peptide (GLP)-1 analog liraglutide for 16 weeks reduced the apoC-III secretion rate and as a consequence plasma apoC-III levels (43). These findings demonstrate that glucose homeostasis is an important regulator of apoC-III metabolism, and that the secretion rate of apoC-III is an important driver for the elevation of TRLs in subjects with type 2 diabetes (43).

The regulation of hepatic apoC-III expression is now reasonably well-understood, but much less is known of the control of apoC-III synthesis and secretion in the intestine. Intriguingly, overexpression of apoC-III has been shown to decrease intestinal secretion of dietary triglycerides into lymph due to impaired lipid uptake into enterocytes, and impaired esterification capacity to form triglyceride in the mucosa (44). Likewise, intestinal apoC-III overexpression has been reported

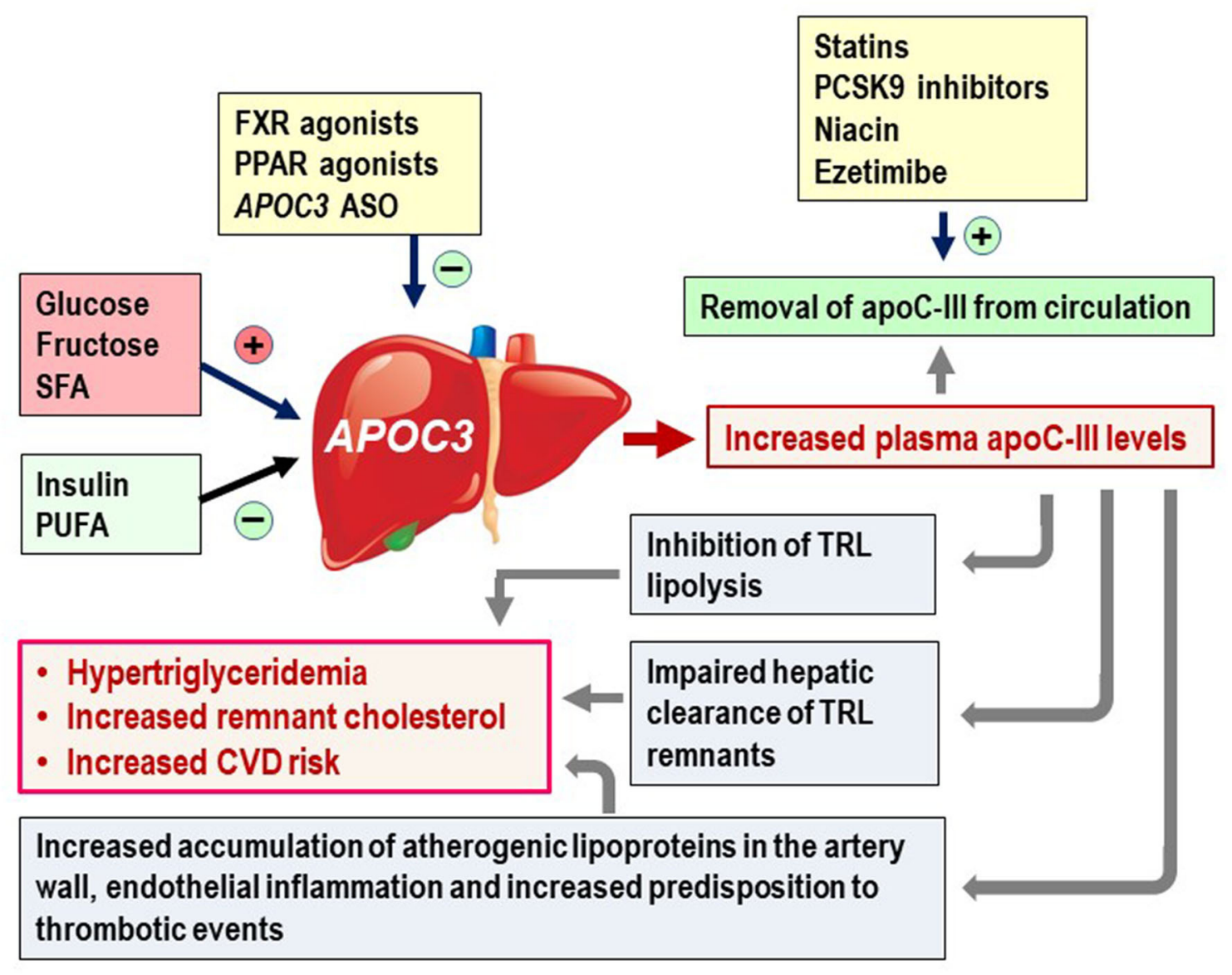

FIGURE 1 | ApoC-III is an important mediator of an atherogenic dyslipidaemia and increased CVD risk. The hepatic APOC3 expression is induced by carbohydrates (glucose and fructose) and saturated fatty acid (SFA), and reduced by insulin and insulin and polyunsaturated fatty acid (PUFA) (18, 19, 31). Pharmacological intervention by FXR $(28,32,33)$ and PPAR $(30,33-36)$ agonists and APOC3 antisense oligonucleotides (ASO) reduces hepatic APOC3 expression (19). Statins (37-39), niacin (40), and ezetimide (40) have been shown to lower plasma apoC-III levels. Increased apoC-III levels induce increase plasma levels of triglycerides and remnant cholesterol, and increased CVD risk. The mechanisms involve impaired lipolysis of TRLs and impaired hepatic clearance of TRL remnants. ApoC-III also facilitates subendothelial accumulation of atherogenic lipoproteins in the artery wall by increasing affinity of atherogenic lipoproteins to artery wall proteoglycans, promoting proinflammatory responses and increasing susceptibility to thrombotic events. 
to result in the secretion of smaller chylomicrons and a reduced triglyceride secretion from the intestine (45).

There is a low concentration of free (i.e., non-lipoprotein associated) apoC-III in the circulation. This form of the protein is chiefly excreted by the kidney (46). It is of note, therefore, that subjects with moderate chronic kidney disease (CKD) which is associated with mild hypertriglyceridemia display increased plasma apoC-III levels due to delayed apoC-III catabolism (47).

\section{HOW DOES APOC-III INDUCE HYPERTRIGLYCERIDEMIA AND INCREASED PLASMA LEVELS OF ATHEROGENIC REMNANT PARTICLES?}

Human kinetic studies have demonstrated that about $20 \%$ of the variation in plasma triglycerides can be explained by increased hepatic production of large triglyceride-rich $\mathrm{VLDL}_{1}$ particles, but that impaired removal of TRLs is the main cause explaining about $55 \%$ of the variation of plasma triglyceride levels (Table 1) (48). Furthermore, reduced clearance rates of TRLs in turn are closely associated with increased plasma apoC-III levels (48). Thus, apoC-III is a key regulator of triglyceride metabolism (Table 1). Further, metabolic studies in hypertriglyceridemic subjects have shown that the removal of TRL particles from the circulation is impaired if they are enriched in apoC-III (49). As noted above, an increased plasma level of apoC-III in states associated with insulin resistance has been implicated as a key driver of the hypertriglyceridemia commonly found in people with this condition. However, somewhat surprisingly, despite increased plasma apoC-III levels in type 2 diabetic subjects, the concentration of VLDL-apoCIII does not increase in line with that of VLDL-triglyceride. That is, VLDL particles do not seem to be enriched with apoC-III $(50,51)$, (although it has been reported that there is an increased concentration of LDL particles carrying apoCIII in subjects with type 2 diabetes) (52). This finding requires further investigation and raises the possibility that it is the free form of apoC-III that is the key modulator of plasma triglyceride levels. Interestingly, Kanter et al. recently reported that plasma apoC-III levels predicted future CVD events in type 1 diabetic subjects with normal triglyceride levels. Also, using two mouse models of T1DM, the authors observed that slowly catabolized lipoproteins, enriched in apoC-III and apoE, may be particularly atherogenic $(53,54)$. Suppressing APOC3 expression with anti-sense oligonucleotides (ASO) lowered both plasma apoC-III levels and atherosclerosis (54). Thus, apoCIII seems to drive accelerate the CVD risk both in T2DM and T1DM (54).

The metabolic and clinical relevance of the three glycoforms of apoC-III has been unclear, but recent studies have shown that the monosialylated apoC- $\mathrm{III}_{1}$ correlates stronger with elevated plasma triglyceride levels than the disialylated apoC- $\mathrm{III}_{2}$ (55, 56 ), and that a higher apoC- $\mathrm{III}_{2} /$ apoC- $-\mathrm{III}_{1}$ ratio associated with lower triglyceride levels (55). It has also been shown that the relative abundances of apoC- $\mathrm{III}_{0}$ and apoC- $\mathrm{III}_{1}$, but not apoC- $\mathrm{III}_{2}$, are associated with lower triglyceride levels after weight loss or diet intervention (57). In accordance with this
TABLE 1 | Key predictors of plasma triglycerides.

\begin{tabular}{|c|c|}
\hline \multicolumn{2}{|c|}{ Key predictors of plas } \\
\hline Synthesis pathway & Liver fat $(r=0.46, p<0.01)$ \\
\hline & Fat mass $(r=0.32, p<0.05)$ \\
\hline \multirow[t]{3}{*}{ Clearance pathway } & Plasma apoC-III concentration $(r=0.84, p<0.001)$ \\
\hline & Plasma apoC-II concentration $(r=0.60, p<0.001)$ \\
\hline & Plasma apoE concentration $(r=0.60, p<0.001)$ \\
\hline \multicolumn{2}{|c|}{$\begin{array}{l}\text { In a stepwise multivariate regression analysis, liver fat content }(P<0.01) \text { and total fat mass } \\
(P<0.05) \text { were identified as independent predictors of } V L D L_{1} \text {-triglyceride secretion rate } \\
(S R)(48) \text {. It was also shown that } V L D L_{1} \text {-triglyceride } S R \text { explained } 76 \% \text { of the variation } \\
\text { in total plasma triglycerides. The effects of apoC-III on plasma triglycerides is mainly } \\
\text { dependent on lipoprotein-lipase independent pathways of triglyceride metabolism (48). } \\
\text { Pearson correlations ( }(r-\text { values) between metabolic characteristics, apolipoproteins, and } \\
\text { plasma triglycerides. The synthesis explains } \approx 20 \% \text { of variation in plasma triglycerides, } \\
\text { and the clearance pathway } \approx 55 \% \text { of variation in plasma triglycerides (48). }\end{array}$} \\
\hline
\end{tabular}

concept, apoC-III ${ }_{2}$ inhibits LPL-mediated hydrolysis of TRLs less efficiently than apoCIII 1 (46), despite having greater affinity for TRLs (58). Interestingly, Kegulian et al. recently reported that the apoC-III glycoforms are differentially cleared by hepatic receptors. Heparan sulfate proteoglycans (HSPGs), in particular syndecan, seem to preferentially clear apoC- $-\mathrm{III}_{2}$, whereas apoC-III $I_{1}$ is preferentially cleared by low-density lipoprotein receptors (LDLR) and LDLR-related protein 1 receptor (LRP1). Interestingly, volanesorsen (a pharmaceutical ASO for APOC3) treatment increased the apoC- $\mathrm{III}_{2} / \mathrm{apoC}-\mathrm{III}_{1}$ ratio, by increasing the relative abundance of apoC- $-\mathrm{III}_{2}$ (by $40 \%$ ) and decreasing that

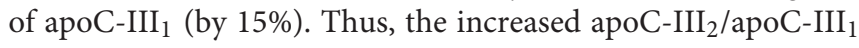
ratio seem to reflect faster clearance of apoC-III ${ }_{1}$.

ApoC-III has also been proposed to increase secretion of VLDL in mice overexpressing apoC-III (59-61). However, suppression of apoC3 expression in mice using an ASO did not influence VLDL secretion (62), and results from kinetic studies in humans are still lacking.

\section{Inhibition of LPL-Mediated Lipolysis of TRLs}

Clearance of plasma triglycerides is directly linked to the lipolysis of TRLs by lipoprotein lipase (LPL) which is attached to the capillary endothelium in adipose tissue, skeletal muscle and the heart (63). ApoC-III is a potent inhibitor of LPL, explaining why increased levels of plasma apoC-III levels correlate with impaired lipolysis of TRLs (Figure 1). The mechanisms involved are not fully elucidated but seem to include weakened binding of TRLs to the capillary endothelium where LPL is present (64), as well as displacement of the LPL activator apoC-II from the surface of the TRLs (15, 65-68).

\section{Impaired Hepatic Clearance of TRL Remnants}

In addition to directly impairing the lipolytic process apoCIII has a wide range of LPL-independent actions on lipid metabolism $(19,60)$. For example, apoC-III ASOs were shown to greatly reduce serum triglycerides in subjects with familial chylomicronemia syndrome where there is a genetic deficiency 
of LPL. It appears that apoC-III can inhibit hepatic clearance of remnants by LPL-independent pathways (Figure 1) (69), possibly by interfering with the binding of apoB and apoE to hepatic lipoprotein receptors including HSPG, LDLR and LRPl (31, 70). Recent results indicate that LDLR and LRPl are involved, since apoC-III ASO treatment in LDLR/LRP1 deficient mice did not lower plasma TG levels (65). The principal ligand on the remnant particles is apoE, and by displacing this protein from the lipoprotein particle surface (66), apoC-III effectively impairs the clearance of remnants (71). As apoC-III displaces both apoC-II and apoE from the lipoproteins, it has been proposed that the apoC-III/apoE ratio on remnant particles predicts the hepatic clearance rate of these lipoproteins (66). Interestingly, Ramms et al. recently proposed a model in which apoE determines the metabolic impact of apoC-III on the metabolism of triglycerides by shifting apoC-III's action from supressing hepatic clearance of TRL to inhibition of LPL (72). The model is based on studies showing that suppressing APOC3 expression in the absence of apoE did not improve clearance of TRLs, yet significantly decreased plasma triglyceride levels in vivo (72). This model is supported by previous clinical studies (66) and by studies using genetically modified Apoc3 ${ }^{-/-}$Apoe ${ }^{-/-}$mice (73). Ramms et al. also showed that the triglyceride-lowering effect induced by apoC-III suppression in the absence of apoE, is mainly due to increased LPL activity in white adipose tissue (WAT) (72). Importantly, the study also demonstrated that the efficiency of volanesorsen to lower plasma triglycerides is not dependent on apoE genotype (72). This is important since apoE3 and apoE4 can bind to LDLR and LRP1, whereas apoE2 does not (72).

\section{DIRECT EFFECTS OF APOC-III ON ATHEROGENESIS}

Atherogenesis is initiated by subendothelial accumulation of atherogenic lipoproteins. This is mediated by ionic interactions between positively charged domains in apoB100 (74), and negatively charged artery wall proteoglycans (75). ApoC-III facilitates this interaction by increasing the affinity of LDL for the artery wall proteoglycans (Figure 1) (52, 76-80). LDL enriched with apoC-III also displays markedly altered lipid composition, with significantly reduced amount of sphingomyelin, unesterified cholesterol, and ceramides (52). The loss of these lipids, but not of phosphatidylcholine, likely affects the surface fluidity of the lipoprotein particle (81). Thus, the altered lipid composition in apoCIII-enriched LDL may induce conformational changes in apoB100 that are more favorable for proteoglycan binding $(52,82,83)$. In line, also apoCIII-enriched HDL display altered lipid composition, with changes in triglycerides, unesterified cholesterol, free cholesterol, phospholipid and apoAI (84).

Following subendothelial retention, LDL are modified by several enzymes, including sphingomyelinases (SMase). This modification promotes both fusion and aggregation of the retained LDL $(85,86)$, as well as release of proinflammatory metabolites including arachidonic acid (87). The aggregation of LDL may also drive an inflammatory response as aggregated LDL is a potent inducer of macrophage foam cell formation (88).
Interestingly, apoC-III acts as a SMase activator. Thus, apoC-III may promote proatherogenic modification of retained LDL in the artery wall, and induce inflammatory responses $(86,89)$. ApoCIII has also been shown to directly activate adhesion molecules and proinflammatory responses in monocytes and endothelial cells (Figure 1) $(90,91)$. In addition, apoC-III levels have also been shown to strongly correlate with plasma levels of activated factor VII-anti-thrombin (FVIIa-AT) complex, a biomarker for increased predisposition to thrombotic events (Figure 1); a strong association was found in both sexes, regardless of whether or not there had been a prior CAD event (92). Thus, apoC-III seems to link lipid metabolism and coagulation. Finally, under conditions of islet insulin resistance, local islet production of apoC-III has been identified as a diabetogenic factor involved in impairment of $\beta$-cell function. Thus, apoC-III synthesized in the pancreas seems to link insulin resistance and $\beta$-cell failure in T2 DM (93).

Capoulade et al. recently reported that apoC-III is present on lipoprotein (a) ( $\mathrm{Lp}(\mathrm{a})$ particles in the circulation and in the aortic valve leaflets (94). Their results indicate that increased plasma levels of apoCIII-Lp(a) complexes in combination with $\mathrm{Lp}(\mathrm{a})$ OxPL may be used to predict aortic stenosis and aortic valve replacement (94).

\section{WHAT HAVE WE LEARNED FROM EPIDEMIOLOGY AND GENETIC STUDIES?}

Epidemiological studies have revealed that plasma levels of apoCIII and apoB independently predict coronary heart disease (14). ApoC-III levels even predict coronary events independent of LDL cholesterol values (2-4). In diabetic subjects, those with LDL with the highest apoC-III content have a six-fold higher relative risk of new coronary events compared to those with LDL with lowest apoC-III content (3). Furthermore, Olivieri et al. recently reported that high plasma apoC-III levels predict an increased risk of ischemic stroke/transient ischemic attack (TIA) events in cardiovascular patients (95).

Large genetic studies have demonstrated that elevated plasma triglyceride is causally linked to coronary artery disease (CAD) (5-9). For example, both the Exome Sequencing Project $(n=$ $1,10,970)$ and the Copenhagen Study $(n=75,725)$ reported that APOC3 LOF mutations had about $40 \%$ lower plasma triglycerides and about $40 \%$ lower CVD risk. These results suggest that $1 \mathrm{mg} / \mathrm{dl}$ decrease in plasma apoC-III concentration translates to a $4 \%$ decrease in CVD incidence (8).

Genetic studies have also shown that carriers of the APOC3 null mutation R19X have 50\% lower plasma apoC-III levels, $35 \%$ lower plasma triglycerides, markedly lower postprandial triglycerides and significantly lower coronary artery calcification (CAC) scores than non-carriers $(96,97)$. Thus, lifelong deficiency of apoC-III is cardioprotective. Carriers of the R19X null mutation display both lower apoC-III production rate and increased apoC-III clearance rate, leading to increased lipolysis of TRLs (96). As expected, the lower plasma apoC-III levels did not influence direct VLDL clearance (i.e., removal of VLDL particles) (96). Carriers of the APOC3 null mutation R19X variant are rare 
[0.08\% in Americans (98) and 0.05\% in Europeans (99)], but the R19X variant is enriched in the Amish population and in an isolated cohort on the island of Crete (100). Heterozygote LOF mutations in APOC 3 have also been shown to associate with high HDL-cholesterol in addition to low plasma triglycerides (101, 102). The heterozygote APOC3 LOF mutation Ala43Thr variant has also been associated with impaired lipidation of nascent VLDL particles during their hepatic assembly (103). Thus, some APOC3 genetic variants may modulate plasma triglyceride levels by mechanisms other than enhanced lipolysis.

Plasma triglyceride levels closely correlate with remnant cholesterol, and genetic studies in apoC-III LOF carriers have made it possible to analyse if remnant cholesterol independently predict ischemic heart disease (IHD) risk (104). Heterozygotes for APOC3 LOF mutations had 43\% lower remnant cholesterol, minor changes in LDL-cholesterol (mean of $-4 \%$ ), and a $13 \%$ lower apoB compared to non-carriers (104). Mediation analysis indicated that about half of the lower risk of IHD in LOF carriers was attributable to the difference in remnant cholesterol and only about $2 \%$ to the difference in LDL cholesterol. This result adds to the Mendelian randomization studies by Ference et al. showing that reductions in triglyceride levels do not reduce CVD risk unless there was an accompanying reduction in circulating apoB levels, and that the reduction in risk was proportional to the decrement in apoB (105). The 36\% lower IHD risk for a 14 $\mathrm{mg} / \mathrm{dl}$ lower apoB in the Copenhagen studies (104) is in line with the $23 \%$ lower risk per $10 \mathrm{mg} / \mathrm{dl}$ decrement in plasma apoB seen by Ference et al. (105). What the former investigation seems to indicate is that is does not matter if the apoB difference is in remnant particles or LDL. This is in line with the notion that any apoB-containing lipoproteins able to penetrate into the artery wall are atherogenic.

As the allele frequency of APOC3 LOF mutations is low, very few homozygous carriers have been identified. However, four homozygotes carriers (Arg19Thr) were recently identified in Pakistan (106). In addition, a family with nine children, all homozygous carriers (Arg19Thr) was recently identified (106). As expected, the homozygotes APOC3 LOF carriers had low very plasma apoC-III levels and markedly blunted postprandial triglyceride responses (106).

\section{CAN DIETS MODULATE PLASMA APOC-III LEVELS?}

Genetic studies clearly show that low plasma levels of apoCIII are cardioprotective. So how can we lower apoC-III? The first option is with dietary intervention. As APOC3 expression is induced by glucose, it's not surprising that the carbohydratecontent of the diet correlates with plasma apoC-III levels (57, 107-110). For example, fructose-enriched diets have been shown to induce several cardiometabolic risk factors including increased apoC-III plasma levels (111-113) and fructose restriction has been shown to lower plasma apoC-III $(112,114)$. In line, a two-week intervention using an isocaloric low-carbohydrate diet $(<30 \mathrm{~g}$ carbohydrates/day) induced an almost $50 \%$ reduction of plasma apoC-III levels in obese subjects with non-alcoholic fatty liver disease (NAFLD) (115). Interestingly, fructose seems to have particularly adverse effects on apoC-III levels since it has been observed that subjects consuming fructose for 10 weeks had higher plasma apoC-III levels and postprandial TRL-triglycerides than subjects consuming an equivalent amount of glucose (116). Interestingly, Hieronimus and Stanhope have recently proposed that apoC-III might be causal for fructose-induced dyslipidaemia since suppression of APOCIII expression in non-human primates prevented fructose-induced dyslipidemia (117).

Fructose induced not only increased expression of APOC3 $(111,113)$, but also increased hepatic de novo lipogenesis of fatty acids that is an important initiator of NAFLD and overproduction of triglyceride-rich $\mathrm{VLDL}_{1}$ particles $(43,61,118$ 122). The relative importance of increased liver fat vs. increased secretion of apoC-III for fructose-induced hypertriglyceridemia, remains to clarified. Consumption of saturated fat has been reported to increase plasma apoC-III levels $(42,123)$, whereas intake of mono- and poly-unsaturated fat associate with reduced plasma apoC-III levels (Figure 1) (123). Also, omega3 polyunsaturated fatty acids have been reported to decrease plasma apoC-III levels $(124,125)$. Whether this mechanism is relevant for their triglyceride-lowering effects remains to be clarified (126).

\section{PHARMACOLOGICAL INTERVENTIONS FOR REDUCING PLASMA APOC-III LEVELS AND HYPERTRIGLYCERIDEMIA}

Earlier studies have reported that PPAR $\alpha$ agonists reduce APOC3 and plasma apoC-III levels $(30,33,127)$. However, the ability of fibrates to reduce $A P O C 3$ expression is highly variable ranging from 10 to $40 \%(37,128-131)$. Even less has been reported on how PPAR $\gamma$ agonists (pioglitazone, rosiglitazone) affect apoCIII metabolism (34, 132). Also, nicotinic acid (niacin) (133) and statin therapy have been shown to reduce hepatic APOC3 expression through largely unknown mechanisms (38). Metaanalyses have revealed that statins reduce plasma apoC-III levels (134) and Ooi et al. reported that that the statin rosuvastatin both decreased the production rate of apoC-III, and simultaneously increased its catabolism (38). Omega-3 carboxylic acids (OM3CA) and polyunsaturated fatty acids have also been shown to reduce plasma apoC-III by $20-30 \%(125,135,136)$. However, compared to the actions of ASOs, these interventions reduce apoC-III levels only to a moderate degree.

Development of novel technologies including ASOs, siRNAs and monoclonal antibodies $(137,138)$, as well as improved targeting methods (139, 140), including use of $\mathrm{N}$-acetyl galactosamine-conjugated (GalNAc) adducts (i.e., the ligand of the hepatic asialoglycoprotein receptor), have enabled unprecendented fast translation of basic science to clinical intervention (141). For example, volanesorsen (IONIS-APOCIII $\mathrm{Rx})$ represents a second-generation 2'-O-methoxyethyl (2'MOE) chimeric antisense therapeutic oligonucleotide that efficiently reduce APOC3 expression (62).

Results from the recent APPROACH trial, a 52-week randomized, double-blind, phase 3 trial of volanesorsenmediated inhibition of APOC3 expression in 66 patients with familial chylomicronemia syndrome, showed that volanesorsen 
induced a $77 \%$ decrease in mean triglyceride levels (mean decrease of $19.3 \mathrm{mmol} / \mathrm{l}$ ), whereas patients receiving placebo had an $18 \%$ increase in mean triglyceride levels. Common adverse events were mild thrombocytopenia and injection-site reactions. These results validate earlier studies showing that apoC-III inhibits not only LPL-dependent but also LPL-independent pathway(s) of TRL clearance (69).

Volanesorsen has in an earlier randomized, double-blind phase 2 trial been shown to markedly lower plasma apoCIII and triglycerides levels in adult patients $(n=46)$ with severe or uncontrolled hypertriglyceridemia (from 4.0 to 22.6 $\mathrm{mmol} / \mathrm{l})$ (142). The results showed dose-dependent decreases of both plasma apoC-III and triglyceride levels (about 80 and $71 \%$ decreases, respectively). Similar results were reported from the COMPASS study which recruited 113 subjects with severe hypertriglyceridemia (5.7 to $14.8 \mathrm{mmol} / \mathrm{l}$ ) (137). A critical reason for treating severe hypertriglyceridemia is to reduce the risk of acute pancreatitis. It is therefore promising that acute pancreatitis were markedly less in hypertriglyceridemic patients treated with volanesorsen than in the placebo group (143).

Volanesorsen has also been shown to successfully improved diabetic dyslipidaemia by reducing both apoC-III $(-88 \%)$ and plasma TG $(-69 \%)$ in 15 overweight or obese subjects with type 2 diabetes (144). Interestingly, the agent not only improved the dyslipidemia, but also improved whole-body insulin sensitivity (by 57\%) as compared to placebo. Thus, results from the novel antisense therapeutic approach seem promising, but data from large-scale and cardiovascular outcome clinical trials are still missing.

The safety, tolerability, and efficacy of AKCEA-APOCIII-LRx, a next generation GalNAc ASO that is targeted to the liver where it suppresses hepatic APOC3 expression, was recently tested. Results showed $89 \%$ in reduction in apoC-III levels, and $66 \%$ reduction in plasma triglycerides (145).

Another novel strategy to lower plasma triglycerides was recently reported by Wolska et al. (146). They developed a dual apoC-II mimetic and apoC-III antagonist (called D6PV) that activates LPL. The peptide was designed by combining biophysical techniques and advanced molecular simulation of apoC-II. D6PV was shown to be more efficient in activating LPL than full-length apoC-III, and was shown to markedly lower plasma triglycerides $(>80 \%)$ in both apoC-II-deficient mice and hAPOC3-transgenic mice. The peptide reduced plasma apoC-III

\section{REFERENCES}

1. Alaupovic P, Mack WJ, Knight-Gibson C, Hodis HN. The role of triglyceride-rich lipoprotein families in the progression of atherosclerotic lesions as determined by sequential coronary angiography from a controlled clinical trial. Arterioscler Thromb Vasc Biol. (1997) 17:715-22. doi: 10.1161/01.ATV.17.4.715

2. Sacks FM, Alaupovic P, Moye LA, Cole TG, Sussex B, Stampfer MJ, et al. VLDL, apolipoproteins B, CIII, and E, and risk of recurrent coronary events in the Cholesterol and Recurrent Events (CARE) trial. Circulation. (2000) 102:1886-92. doi: 10.1161/01.CIR.102.16.1886

3. Lee SJ, Campos H, Moye LA, Sacks FM. LDL containing apolipoprotein CIII is an independent risk factor for coronary events in diabetic patients. Arterioscler Thromb Vasc Biol. (2003) 23:853-8. doi: 10.1161/01.ATV.0000066131.01313.EB levels by $80 \%$ and apoB levels by $65 \%$. The peptide remains in the circulation for to $50 \mathrm{~h}$ in non-human primates, as it binds to HDL particles. Thus, the results are encouraging but the project is still in early development (147).

\section{CONCLUDING REMARKS AND REMAINING QUESTIONS}

Interest in apoC-III as a novel intervention target has been driven by epidemiological studies demonstrating that plasma apoC-III levels predict coronary events independent of LDL cholesterol values (2-4), and genetic studies demonstrating that APOC3 LOF mutations associate with lower plasma triglycerides and about $40 \%$ lower CVD risk. Recent studies have shown that glucose is an important regulator of apoC-III metabolism $(19,43)$, and that increased hepatic secretion of apoC-III is an important driver for the hypertriglyceridemia commonly seen in subjects with impaired glucose homeostasis (43). The lower CVD risk associated with APOC3 LOF mutations is likely not related to lower plasma triglycerides per se, but may depend on lower plasma concentrations of atherogenic remnant particles. Thus, suppression of hepatic APOC3 expression has become an interesting novel treatment for reducing hypertriglyceridemia and accumulation of atherogenic remnant particles. However, there are some concerns as the treatment has shown less marked response on apoB reduction, than for example suppression of ANGPTL3 that seems to reduce plasma apoB levels more efficiently (148). Long-term clinical studies will be critical for clarifying the protective potential of APOC3 ASO. It will also be interesting to see if this treatment has direct effects on hepatic VLDL secretion, and markers of arterial wall inflammation.

\section{AUTHOR CONTRIBUTIONS}

All authors listed have made a substantial, direct and intellectual contribution to the work, and approved it for publication.

\section{FUNDING}

Swedish Research Council, Swedish Heart-Lung Foundation, ALF grant Sahlgrenska University Hospital, Sigrid Juselius Foundation, Helsinki University Hospital Government Research funds, and Finnish Foundation for Cardiovascular Research.

4. Gervaise N, Garrigue MA, Lasfargues G, Lecomte P. Triglycerides, apo C3 and Lp B:C3 and cardiovascular risk in type II diabetes. Diabetologia. (2000) 43:703-8. doi: 10.1007/s0012500 51366

5. Liu DJ, Peloso GM, Yu H, Butterworth AS, Wang X, Mahajan A, et al. Exomewide association study of plasma lipids in $>300,000$ individuals. Nat Genet. (2017) 49:1758-66. doi: 10.1038/ng.3977

6. Klarin D, Damrauer SM, Cho K, Sun YV, Teslovich TM, Honerlaw J, et al. Genetics of blood lipids among 300,000 multi-ethnic participants of the Million Veteran Program. Nat Genet. (2018) 50:1514-123. doi: 10.1038/s41588-018-0222-9

7. Tall AR. Increasing lipolysis and reducing atherosclerosis. $N$ Engl J Med. (2017) 377:280-3. doi: 10.1056/NEJMe1706907

8. The TG and HDL Working Group of the Exome Sequencing Project, National Heart, Lung, and Blood Institute. Loss-of-function mutations in 
APOC3, triglycerides, coronary disease. N Engl J Med. (2014) 371:22-31. doi: 10.1056/NEJMoa1307095

9. Jorgensen AB, Frikke-Schmidt R, Nordestgaard BG, Tybjaerg-Hansen A. Loss-of-function mutations in APOC3 and risk of ischemic vascular disease. N Engl J Med. (2014) 371:32-41. doi: 10.1056/NEJMoa1308027

10. Wolska A, Reimund M, Remaley AT. Apolipoprotein C-II: the reemergence of a forgotten factor. Curr Opin Lipidol. (2020) 31:147-53. doi: 10.1097/MOL.0000000000000680

11. van Dijk KW, Rensen PC, Voshol PJ, Havekes LM. The role and mode of action of apolipoproteins CIII and AV: synergistic actors in triglyceride metabolism? Curr Opin Lipidol. (2004) 15:239-46. doi: 10.1097/00041433-200406000-00002

12. Gangabadage CS, Zdunek J, Tessari M, Nilsson S, Olivecrona G, Wijmenga SS. Structure and dynamics of human apolipoprotein CIII. J Biol Chem. (2008) 283:17416-27. doi: 10.1074/jbc.M800756200

13. Jong MC, Hofker MH, Havekes LM. Role of ApoCs in lipoprotein metabolism: functional differences between ApoC1, ApoC2, and ApoC3. Arterioscler Thromb Vasc Biol. (1999) 19:472-84. doi: 10.1161/01.ATV.19.3.472

14. Alaupovic P. Significance of apolipoproteins for structure, function, and classification of plasma lipoproteins. Methods Enzymol. (1996) 263:32-60. doi: 10.1016/S0076-6879(96)63004-3

15. Campos H, Perlov D, Khoo C, Sacks FM. Distinct patterns of lipoproteins with apoB defined by presence of apoE or apoC-III in hypercholesterolemia and hypertriglyceridemia. J Lipid Res. (2001) 42:1239-49.

16. Khoo C, Campos H, Judge H, Sacks FM. Effects of estrogenic oral contraceptives on the lipoprotein B particle system defined by apolipoproteins E and C-III content. J Lipid Res. (1999) 40:202-12.

17. Wyler von Ballmoos MC, Haring B, Sacks FM. The risk of cardiovascular events with increased apolipoprotein CIII: A systematic review and metaanalysis. J Clin Lipidol. (2015) 9:498-510. doi: 10.1016/j.jacl.2015.05.002

18. Taskinen MR, Boren J. Why is apolipoprotein CIII emerging as a novel therapeutic target to reduce the burden of cardiovascular disease? Curr Atheroscler Rep. (2016) 18:59. doi: 10.1007/s11883-016-0614-1

19. Norata GD, Tsimikas S, Pirillo A, Catapano AL. Apolipoprotein C-III: from pathophysiology to pharmacology. Trends Pharmacol Sci. (2015) 36:675-87. doi: 10.1016/j.tips.2015.07.001

20. Kohan AB. Apolipoprotein C-III: a potent modulator of hypertriglyceridemia and cardiovascular disease. Curr Opin Endocrinol Diabetes Obes. (2015) 22:119-25. doi: 10.1097/MED.0000000000000136

21. Brown WV, Levy RI, Fredrickson DS. Studies of the proteins in human plasma very low density lipoproteins. J Biol Chem. (1969) 244:5687-94.

22. Liu H, Talmud PJ, Lins L, Brasseur R, Olivecrona G, Peelman F, et al. Characterization of recombinant wild type and site-directed mutations of apolipoprotein C-III: lipid binding, displacement of ApoE, and inhibition of lipoprotein lipase. Biochemistry. (2000) 39:9201-12. doi: 10.1021/bi0009441

23. Sparrow JT, Pownall HJ, Hsu FJ, Blumenthal LD, Culwell AR, Gotto AM. Lipid binding by fragments of apolipoprotein C-III-1 obtained by thrombin cleavage. Biochemistry. (1977) 16:5427-31. doi: 10.1021/bi00644a004

24. Lins L, Flore C, Chapelle L, Talmud PJ, Thomas A, Brasseur R. Lipidinteracting properties of the $\mathrm{N}$-terminal domain of human apolipoprotein C-III. Protein Eng. (2002) 15:513-20. doi: 10.1093/protein/15.6.513

25. Meyers NL, Larsson M, Vorrsjo E, Olivecrona G, Small DM. Aromatic residues in the $\mathrm{C}$ terminus of apolipoprotein C-III mediate lipid binding and LPL inhibition. J Lipid Res. (2017) 58:840-52. doi: 10.1194/jlr.M071126

26. Trenchevska O, Schaab MR, Nelson RW, Nedelkov D. Development of multiplex mass spectrometric immunoassay for detection and quantification of apolipoproteins C-I, C-II, C-III and their proteoforms. Methods. (2015) 81:86-92. doi: 10.1016/j.ymeth.2015.02.020

27. Kegulian NC, Ramms B, Horton S, Trenchevska O, Nedelkov D, Graham MJ, et al. ApoC-III glycoforms are differentially cleared by hepatic TRL (Triglyceride-Rich Lipoprotein) receptors. Arterioscler Thromb Vasc Biol. (2019) 39:2145-56. doi: 10.1161/ATVBAHA.119.312723

28. Chen M, Breslow JL, Li W, Leff T. Transcriptional regulation of the apoCIII gene by insulin in diabetic mice: correlation with changes in plasma triglyceride levels. J Lipid Res. (1994) 35:1918-24.

29. Altomonte J, Cong L, Harbaran S, Richter A, Xu J, Meseck M, et al. Foxo1 mediates insulin action on apoC-III and triglyceride metabolism. J Clin Investig. (2004) 114:1493-503. doi: 10.1172/JCI200419992
30. Hertz R, Bishara-Shieban J, Bar-Tana J. Mode of action of peroxisome proliferators as hypolipidemic drugs. Suppression of apolipoprotein C-III. J Biol Chem. (1995). 270:13470-5. doi: 10.1074/jbc.270.22.13470

31. Ramms B, Gordts P. Apolipoprotein C-III in triglyceride-rich lipoprotein metabolism. Curr Opin Lipidol. (2018) 29:171-179. doi: 10.1097/MOL.0000000000000502

32. Claudel $\mathrm{T}$, Inoue $\mathrm{Y}$, Barbier $\mathrm{O}$, Duran-Sandoval $\mathrm{D}$, Kosykh $\mathrm{V}$, Fruchart J, et al. Farnesoid $\mathrm{X}$ receptor agonists suppress hepatic apolipoprotein CIII expression. Gastroenterology. (2003) 125:544-55. doi: 10.1016/S0016-5085(03)00896-5

33. Staels B, Vu-Dac N, Kosykh VA, Saladin R, Fruchart JC, Dallongeville J, et al. Fibrates downregulate apolipoprotein C-III expression independent of induction of peroxisomal acyl coenzyme A oxidase. A potential mechanism for the hypolipidemic action of fibrates. J Clin Invest. (1995) 95:705-12. doi: $10.1172 / J C I 117717$

34. Nagashima K, Lopez C, Donovan D, Ngai C, Fontanez N, Bensadoun A, et al. Effects of the PPARgamma agonist pioglitazone on lipoprotein metabolism in patients with type 2 diabetes mellitus. J Clin Invest. (2005) 115:1323-32. doi: 10.1172/JCI200523219

35. Fagerberg B, Edwards S, Halmos T, Lopatynski J, Schuster H, Stender $S$, et al. Tesaglitazar, a novel dual peroxisome proliferator-activated receptor alpha/gamma agonist, dose-dependently improves the metabolic abnormalities associated with insulin resistance in a non-diabetic population. Diabetologia. (2005) 48:1716-25. doi: 10.1007/s00125-005-1846-8

36. Schuster H, Fagerberg B, Edwards S, Halmos T, Lopatynski J, Stender $\mathrm{S}$, et al. Tesaglitazar, a dual peroxisome proliferator-activated receptor alpha/gamma agonist, improves apolipoprotein levels in non-diabetic subjects with insulin resistance. Atherosclerosis. (2008) 197:355-62. doi: 10.1016/j.atherosclerosis.2007.05.029

37. Chan DC, Watts GF, Ooi EM, Ji J, Johnson AG, Barrett PH. Atorvastatin and fenofibrate have comparable effects on VLDL-apolipoprotein C-III kinetics in men with the metabolic syndrome. Arterioscler Thromb Vasc Biol. (2008) 28:1831-7. doi: 10.1161/ATVBAHA.108.170530

38. Ooi EM, Watts GF, Chan DC, Chen MM, Nestel PJ, Sviridov D, et al. Dose-dependent effect of rosuvastatin on VLDL-apolipoprotein C-III kinetics in the metabolic syndrome. Diabetes Care. (2008) 31:1656-61. doi: $10.2337 / \mathrm{dc} 08-0358$

39. Dallinga-Thie GM, Berk P, II, Bootsma AH, Jansen H, Diabetes Atorvastatin Lipid intervention Study G. Atorvastatin decreases apolipoprotein C-III in apolipoprotein B-containing lipoprotein and HDL in type 2 diabetes: a potential mechanism to lower plasma triglycerides. Diabetes Care. (2004) 27:1358-64. doi: 10.2337/diacare.27.6.1358

40. Ooi EM, Barrett PH, Chan DC, Watts GF. Apolipoprotein C-III: understanding an emerging cardiovascular risk factor. Clin Sci. (2008) 114:611-24. doi: 10.1042/CS20070308

41. Caron S, Verrijken A, Mertens I, Samanez CH, Mautino G, Haas JT, et al. Transcriptional activation of apolipoprotein CIII expression by glucose may contribute to diabetic dyslipidemia. Arterioscler Thromb Vasc Biol. (2011) 31:513-9. doi: 10.1161/ATVBAHA.110.220723

42. Pavlic M, Valero R, Duez H, Xiao C, Szeto L, Patterson BW, et al. Triglyceride-rich lipoprotein-associated apolipoprotein C-III production is stimulated by plasma free fatty acids in humans. Arterioscler Thromb Vasc Biol. (2008) 28:1660-5. doi: 10.1161/ATVBAHA.108.169383

43. Adiels M, Taskinen MR, Bjornson E, Andersson L, Matikainen N, Soderlund S, et al. Role of apolipoprotein C-III overproduction in diabetic dyslipidaemia. Diabetes Obes Metab. (2019) 21:1861-70. doi: 10.1111/dom.13744

44. Wang F, Kohan AB, Dong HH, Yang Q, Xu M, Huesman S, et al. Overexpression of apolipoprotein C-III decreases secretion of dietary triglyceride into lymph. Physiol Rep. (2014) 2:e00247. doi: 10.1002/phy2.247

45. Jattan J, Rodia C, Li D, Diakhate A, Dong H, Bataille A, et al. Using primary murine intestinal enteroids to study dietary TAG absorption, lipoprotein synthesis, and the role of apoC-III in the intestine. J Lipid Res. (2017) 58:853-65. doi: 10.1194/jlr.M071340

46. Holdsworth G, Stocks J, Dodson P, Galton DJ. An abnormal triglyceride-rich lipoprotein containing excess sialylated apolipoprotein C-III. J Clin Invest. (1982) 69:932-9. doi: 10.1172/JCI110532

47. Ooi EM, Chan DT, Watts GF, Chan DC, Ng TW, Dogra GK, et al. Plasma apolipoprotein C-III metabolism in patients with chronic 
kidney disease. J Lipid Res. (2011) 52:794-800. doi: 10.1194/jlr.M0 11163

48. Boren J, Watts GF, Adiels M, Soderlund S, Chan DC, Hakkarainen A, et al. Kinetic and related determinants of plasma triglyceride concentration in abdominal obesity: multicenter tracer kinetic study. Arterioscler Thromb Vasc Biol. (2015) 35:2218-24. doi: 10.1161/ATVBAHA.115.305614

49. Zheng C, Khoo C, Furtado J, Sacks FM. Apolipoprotein C-III and the metabolic basis for hypertriglyceridemia and the dense lowdensity lipoprotein phenotype. Circulation. (2010) 121:1722-34. doi: 10.1161/CIRCULATIONAHA.109.875807

50. Lee SJ, Moye LA, Campos H, Williams GH, Sacks FM. Hypertriglyceridemia but not diabetes status is associated with VLDL containing apolipoprotein CIII in patients with coronary heart disease. Atherosclerosis. (2003) 167:293302. doi: 10.1016/\$0021-9150(03)00007-8

51. Hiukka A, Fruchart-Najib J, Leinonen E, Hilden H, Fruchart JC, Taskinen MR. Alterations of lipids and apolipoprotein CIII in very low density lipoprotein subspecies in type 2 diabetes. Diabetologia. (2005) 48:1207-15. doi: $10.1007 /$ s00125-005-1753-z

52. Hiukka A, Stahlman M, Pettersson C, Levin M, Adiels M, Teneberg S, et al. ApoCIII-enriched LDL in type 2 diabetes displays altered lipid composition, increased susceptibility for sphingomyelinase, and increased binding to biglycan. Diabetes. (2009) 58:2018-26. doi: 10.2337/db09-0206

53. Ginsberg HN, Reyes-Soffer G. Is APOC3 the driver of cardiovascular disease in people with type I diabetes mellitus? J Clin Invest. (2019) 129:4074-6. doi: $10.1172 /$ JCI131333

54. Kanter JE, Shao B, Kramer F, Barnhart S, Shimizu-Albergine M, Vaisar T, et al. Increased apolipoprotein C3 drives cardiovascular risk in type 1 diabetes. J Clin Invest. (2019) 130:4165-79. doi: 10.1172/JCI127308

55. Koska J, Yassine H, Trenchevska O, Sinari S, Schwenke DC, Yen FT, et al. Disialylated apolipoprotein C-III proteoform is associated with improved lipids in prediabetes and type 2 diabetes. J Lipid Res. (2016) 57:894-905. doi: 10.1194/jlr.P064816

56. Yassine HN, Trenchevska O, Ramrakhiani A, Parekh A, Koska J, Walker RW, et al. The Association of human apolipoprotein C-III sialylation proteoforms with plasma triglycerides. PLoS ONE. (2015) 10:e0144138. doi: 10.1371/journal.pone.0144138

57. Mendoza S, Trenchevska O, King SM, Nelson RW, Nedelkov D, Krauss $\mathrm{RM}$, et al. Changes in low-density lipoprotein size phenotypes associate with changes in apolipoprotein C-III glycoforms after dietary interventions. J Clin Lipidol. (2017) 11:224-33 e2. doi: 10.1016/j.jacl.2016.12.009

58. Mann CJ, Troussard AA, Yen FT, Hannouche N, Najib J, Fruchart JC, et al. Inhibitory effects of specific apolipoprotein C-III isoforms on the binding of triglyceride-rich lipoproteins to the lipolysis-stimulated receptor. J Biol Chem. (1997) 272:31348-54. doi: 10.1074/jbc.272.50.31348

59. Yao Z. Human apolipoprotein C-III - a new intrahepatic protein factor promoting assembly and secretion of very low density lipoproteins. Cardiovasc Hematol Disord Drug Targets. (2012) 12:133-40. doi: 10.2174/1871529X11202020133

60. Taskinen MR, Boren J. New insights into the pathophysiology of dyslipidemia in type 2 diabetes. Atherosclerosis. (2015) 239:483-95. doi: 10.1016/j.atherosclerosis.2015.01.039

61. Adiels M, Olofsson SO, Taskinen MR, Boren J. Overproduction of very low-density lipoproteins is the hallmark of the dyslipidemia in the metabolic syndrome. Arterioscler Thromb Vasc Biol. (2008) 28:1225-36. doi: 10.1161/ATVBAHA.107.160192

62. Graham MJ, Lee RG, Bell TA, 3rd, Fu W, Mullick AE, Alexander VJ, et al. Antisense oligonucleotide inhibition of apolipoprotein C-III reduces plasma triglycerides in rodents, nonhuman primates, and humans. Circ Res. (2013) 112:1479-90. doi: 10.1161/CIRCRESAHA.111.300367

63. Ginsberg HN, Le NA, Goldberg IJ, Gibson JC, Rubinstein A, WangIverson P, et al. Apolipoprotein B metabolism in subjects with deficiency of apolipoproteins CIII and AI. Evidence that apolipoprotein CIII inhibits catabolism of triglyceride-rich lipoproteins by lipoprotein lipase in vivo. J Clin Invest. (1986) 78:1287-95. doi: 10.1172/JCI1 12713

64. Ebara T, Ramakrishnan R, Steiner G, Shachter NS. Chylomicronemia due to apolipoprotein CIII overexpression in apolipoprotein E-null mice. Apolipoprotein CIII-induced hypertriglyceridemia is not mediated by effects on apolipoprotein E. J Clin Invest. (1997) 99:2672-81. doi: 10.1172/JCI119456

65. Gordts PL, Nock R, Son NH, Ramms B, Lew I, Gonzales JC, et al. ApoCIII inhibits clearance of triglyceride-rich lipoproteins through LDL family receptors. J Clin Invest. (2016) 126:2855-66. doi: 10.1172/JCI86610

66. Sacks FM. The crucial roles of apolipoproteins E and C-III in apoB lipoprotein metabolism in normolipidemia and hypertriglyceridemia. Curr Opin Lipidol. (2015) 26:56-63. doi: 10.1097/MOL.0000000000000146

67. Larsson M, Vorrsjo E, Talmud P, Lookene A, Olivecrona G. Apolipoproteins C-I and C-III inhibit lipoprotein lipase activity by displacement of the enzyme from lipid droplets. J Biol Chem. (2013) 288:33997-4008. doi: 10.1074/jbc.M113.495366

68. Lambert DA, Smith LC, Pownall H, Sparrow JT, Nicolas JP, Gotto AM Jr. Hydrolysis of phospholipids by purified milk lipoprotein lipase. Effect of apoprotein CII, CIII, A and E, synthetic fragments. Clin Chim Acta. (2000) 291:19-33. doi: 10.1016/S0009-8981(99)00193-X

69. Gaudet D, Brisson D, Tremblay K, Alexander VJ, Singleton W, Hughes SG, et al. Targeting APOC3 in the familial chylomicronemia syndrome. $N$ Engl $J$ Med. (2014) 371:2200-6. doi: 10.1056/NEJMoa1400284

70. Williams KJ. Molecular processes that handle - and mishandle - dietary lipids. J Clin Invest. (2008) 118:3247-59. doi: 10.1172/JCI35206

71. Narayanaswami V, Ryan RO. Molecular basis of exchangeable apolipoprotein function. Biochim Biophys Acta. (2000) 1483:15-36. doi: 10.1016/S1388-1981(99)00176-6

72. Ramms B, Patel S, Nora C, Pessentheiner AR, Chang MW, Green CR, et al. ApoC-III ASO promotes tissue LPL activity in the absence of apoE-mediated TRL clearance. J Lipid Res. (2019) 60:1379-95. doi: 10.1194/jlr.M093740

73. Jong MC, Rensen PC, Dahlmans VE, van der Boom H, van Berkel TJ, Havekes LM. Apolipoprotein C-III deficiency accelerates triglyceride hydrolysis by lipoprotein lipase in wild-type and apoE knockout mice. J Lipid Res. (2001) 42:1578-85.

74. Boren J, Olin K, Lee I, Chait A, Wight TN, Innerarity TL. Identification of the principal proteoglycan-binding site in LDL. A single-point mutation in apo-B100 severely affects proteoglycan interaction without affecting LDL receptor binding. J Clin Invest. (1998) 101:2658-64. doi: 10.1172/JCI2265

75. Skalen K, Gustafsson M, Rydberg EK, Hulten LM, Wiklund O, Innerarity $\mathrm{TL}$, et al. Subendothelial retention of atherogenic lipoproteins in early atherosclerosis. Nature. (2002) 417:750-4. doi: 10.1038/nature00804

76. Olin-Lewis K, Krauss RM, La Belle M, Blanche PJ, Barrett PH, Wight TN, et al. ApoC-III content of apoB-containing lipoproteins is associated with binding to the vascular proteoglycan biglycan. J Lipid Res. (2002) 43:1969-77. doi: 10.1194/jlr.M200322-JLR200

77. Davidsson P, Hulthe J, Fagerberg B, Olsson BM, Hallberg C, Dahllof B, et al. A proteomic study of the apolipoproteins in LDL subclasses in patients with the metabolic syndrome and type 2 diabetes. J Lipid Res. (2005) 46:1999-2006. doi: 10.1194/jlr.M500161-JLR200

78. Boren J, Gustafsson M, Skalen K, Flood C, Innerarity TL. Role of extracellular retention of low density lipoproteins in atherosclerosis. Curr Opin Lipidol. (2000) 11:451-6. doi: 10.1097/00041433-200010000-00002

79. Gustafsson M, Boren J. Mechanism of lipoprotein retention by the extracellular matrix. Curr Opin Lipidol. (2004) 15:505-14. doi: 10.1097/00041433-200410000-00003

80. Gustafsson M, Flood C, Jirholt P, Boren J. Retention of atherogenic lipoproteins in atherogenesis. Cell Mol Life Sci. (2004) 61:4-9. doi: $10.1007 / \mathrm{s} 00018-003-3262-\mathrm{x}$

81. Sola R, Baudet MF, Motta C, Maille M, Boisnier C, Jacotot B. Effects of dietary fats on the fluidity of human high-density lipoprotein: influence of the overall composition and phospholipid fatty acids. Biochim Biophys Acta. (1990) 1043:43-51. doi: 10.1016/0005-2760(90)90108-A

82. Segrest J, Jones M, Mishra V, Pierotti V, Young S, Boren J, et al. Apolipoprotein B-100: conservation of lipid-associating amphipathic secondary structural motifs in nine species of vertebrates. J Lipid Res. (1998) 3:85-102.

83. Flood C, Gustafsson M, Pitas RE, Arnaboldi L, Walzem RL, Boren J. Molecular mechanism for changes in proteoglycan binding on compositional changes of the core and the surface of low-density lipoprotein-containing human apolipoprotein B100. Arterioscler Thromb Vasc Biol. (2004) 24:56470. doi: 10.1161/01.ATV.0000117174.19078.85 
84. Zhang T, Tang X, Mao L, Chen J, Kuang J, Guo X, et al. HDLassociated apoCIII plays an independent role in predicting postprandial hypertriglyceridemia. Clin Biochem. (2020) 79:14-22. doi: 10.1016/j.clinbiochem.2020.02.004

85. Oorni K, Hakala JK, Annila A, Ala-Korpela M, Kovanen PT. Sphingomyelinase induces aggregation and fusion, but phospholipase A2 only aggregation, of low density lipoprotein (LDL) particles. Two distinct mechanisms leading to increased binding strength of LDL to human aortic proteoglycans. J Biol Chem. (1998) 273:29127-34. doi: $10.1074 /$ jbc.273.44.29127

86. Schissel SL, Jiang X, Tweedie-Hardman J, Jeong T, Camejo EH, Najib J, et al. Secretory sphingomyelinase, a product of the acid sphingomyelinase gene, can hydrolyze atherogenic lipoproteins at neutral $\mathrm{pH}$. Implications for atherosclerotic lesion development. J Biol Chem. (1998) 273:2738-46. doi: $10.1074 /$ jbc. 273.5 .2738

87. Oestvang J, Bonnefont-Rousselot D, Ninio E, Hakala JK, Johansen B, Anthonsen MW. Modification of LDL with human secretory phospholipase $\mathrm{A}(2)$ or sphingomyelinase promotes its arachidonic acid-releasing propensity. J Lipid Res. (2004) 45:831-8. doi: 10.1194/jlr.M300310-JLR200

88. Hoff HF, O’Neil J, Pepin JM, Cole TB. Macrophage uptake of cholesterol-containing particles derived from LDL and isolated from atherosclerotic lesions. Eur Heart J. (1990) 11 (Suppl. E):105-15. doi: 10.1093/eurheartj/11.suppl_E.105

89. Ruuth M, Nguyen SD, Vihervaara T, Hilvo M, Laajala TD, Kondadi PK, et al. Susceptibility of low-density lipoprotein particles to aggregate depends on particle lipidome, is modifiable, and associates with future cardiovascular deaths. Eur Heart J. (2018) 39:2562-73. doi: 10.1093/eurheartj/ehy319

90. Kawakami A, Aikawa M, Alcaide P, Luscinskas FW, Libby P, Sacks FM. Apolipoprotein CIII induces expression of vascular cell adhesion molecule-1 in vascular endothelial cells and increases adhesion of monocytic cells. Circulation. (2006) 114:681-7. doi: 10.1161/CIRCULATIONAHA.106.622514

91. Kawakami A, Aikawa M, Nitta N, Yoshida M, Libby P, Sacks FM. Apolipoprotein CIII-induced THP-1 cell adhesion to endothelial cells involves pertussis toxin-sensitive $G$ protein- and protein kinase $C$ alpha-mediated nuclear factor-kappaB activation. Arterioscler Thromb Vasc Biol. (2007) 27:219-25. doi: 10.1161/01.ATV.0000249620.68 705.0d

92. Martinelli N, Baroni M, Castagna A, Lunghi B, Stefanoni F, Tosi F, et al. Apolipoprotein C-III strongly correlates with activated factor VII-anti-thrombin complex: an additional link between plasma lipids and coagulation. Thromb Haemost. (2019) 119:192-202. doi: 10.1055/s-0038-1676817

93. Avall K, Ali Y, Leibiger IB, Leibiger B, Moede T, Paschen M, et al. Apolipoprotein CIII links islet insulin resistance to beta-cell failure in diabetes. Proc Natl Acad Sci USA. (2015) 112:E2611-9. doi: 10.1073/pnas.1423849112

94. Capoulade R, Torzewski M, Mayr M, Chan KL, Mathieu P, Bosse $\mathrm{Y}$, et al. ApoCIII-Lp(a) complexes in conjunction with $\mathrm{Lp}(\mathrm{a})-\mathrm{OxPL}$ predict rapid progression of aortic stenosis. Heart. (2020) 106:738-45. doi: 10.1136/heartjnl-2019-315840

95. Olivieri O, Cappellari M, Turcato G, Bonetti B, Girelli D, Pizzolo $\mathrm{F}$, et al. Increased incidence of ischemic cerebrovascular events in cardiovascular patients with elevated apolipoprotein CIII. Stroke. (2020) 51:61-8. doi: 10.1161/STROKEAHA.119.026811

96. Reyes-Soffer G, Sztalryd C, Horenstein RB, Holleran S, Matveyenko A, Thomas T, et al. Effects of APOC3 heterozygous deficiency on plasma lipid and lipoprotein metabolism. Arterioscler Thromb Vasc Biol. (2019) 39:63-72. doi: 10.1161/ATVBAHA.118.311476

97. Pollin TI, Damcott CM, Shen H, Ott SH, Shelton J, Horenstein RB, et al. A null mutation in human APOC3 confers a favorable plasma lipid profile and apparent cardioprotection. Science. (2008) 322:1702-5. doi: $10.1126 /$ science. 1161524

98. Crawford DC, Dumitrescu L, Goodloe R, Brown-Gentry K, Boston J, McClellan B, et al. Rare variant APOC3 R19X is associated with cardio-protective profiles in a diverse population-based survey as part of the Epidemiologic Architecture for Genes Linked to Environment Study. Circ Cardiovasc Genet. (2014) 7:848-53. doi: 10.1161/CIRCGENETICS.113.000369
99. Muddyman D, Smee C, Griffin H, Kaye J. Implementing a successful datamanagement framework: the UK10K managed access model. Genome Med. (2013) 5:100. doi: 10.1186/gm504

100. Tachmazidou I, Dedoussis G, Southam L, Farmaki AE, Ritchie GR, Xifara $\mathrm{DK}$, et al. A rare functional cardioprotective APOC3 variant has risen in frequency in distinct population isolates. Nat Commun. (2013) 4:2872. doi: $10.1038 /$ ncomms 3872

101. Bochem AE, van Capelleveen JC, Dallinga-Thie GM, Schimmel AW, Motazacker MM, Tietjen I, et al. Two novel mutations in apolipoprotein C3 underlie atheroprotective lipid profiles in families. Clin Genet. (2014) 85:433-40. doi: 10.1111/cge.12201

102. Liu H, Labeur C, Xu CF, Ferrell R, Lins L, Brasseur R, et al. Characterization of the lipid-binding properties and lipoprotein lipase inhibition of a novel apolipoprotein C-III variant Ala23Thr. J Lipid Res. (2000) 41:1760-71.

103. Sundaram M, Curtis KR, Amir Alipour M, LeBlond ND, Margison KD, Yaworski RA, et al. The apolipoprotein C-III (Gln38Lys) variant associated with human hypertriglyceridemia is a gain-of-function mutation. J Lipid Res. (2017) 58:2188-96. doi: 10.1194/jlr.M077313

104. Wulff AB, Nordestgaard BG, Tybjaerg-Hansen A. APOC3 Loss-offunction mutations, remnant cholesterol, low-density lipoprotein cholesterol, and cardiovascular risk: mediation- and meta-analyses of 137895 individuals. Arterioscler Thromb Vasc Biol. (2018) 38:660-8. doi: 10.1161/ATVBAHA.117.310473

105. Ference BA, Kastelein JJP, Ray KK, Ginsberg HN, Chapman MJ, Packard CJ, et al. Association of triglyceride-lowering LPL variants and LDL-C-lowering LDLR variants with risk of coronary heart disease. JAMA. (2019) 321:364-73. doi: 10.1001/jama.2018.20045

106. Saleheen D, Natarajan P, Armean IM, Zhao W, Rasheed A, Khetarpal SA, et al. Human knockouts and phenotypic analysis in a cohort with a high rate of consanguinity. Nature. (2017) 544:235-9. doi: 10.1038/nature22034

107. Huff MW, Nestel PJ. Metabolism of apolipoproteins CII, CIII1, CIII2 and VLDL-B in human subjects consuming high carbohydrate diets. Metabolism. (1982) 31:493-8. doi: 10.1016/0026-0495(82)90240-2

108. Archer WR, Desroches S, Lamarche B, Deriaz O, Landry N, FontaineBisson B, et al. Variations in plasma apolipoprotein C-III levels are strong correlates of the triglyceride response to a high-monounsaturated fatty acid diet and a high-carbohydrate diet. Metabolism. (2005) 54:1390-7. doi: 10.1016/j.metabol.2005.05.004

109. Furtado JD, Campos H, Appel LJ, Miller ER, Laranjo N, Carey VJ, et al. Effect of protein, unsaturated fat, and carbohydrate intakes on plasma apolipoprotein B and VLDL and LDL containing apolipoprotein C-III: results from the Omni Heart Trial. Am J Clin Nutr. (2008) 87:1623-30. doi: 10.1093/ajcn/87.6.1623

110. Shin MJ, Blanche PJ, Rawlings RS, Fernstrom HS, Krauss RM. Increased plasma concentrations of lipoprotein(a) during a low-fat, high-carbohydrate diet are associated with increased plasma concentrations of apolipoprotein C-III bound to apolipoprotein B-containing lipoproteins. Am J Clin Nutr. (2007) 85:1527-32. doi: 10.1093/ajcn/85.6.1527

111. Taskinen MR, Soderlund S, Bogl LH, Hakkarainen A, Matikainen N, Pietilainen $\mathrm{KH}$, et al. Adverse effects of fructose on cardiometabolic risk factors and hepatic lipid metabolism in subjects with abdominal obesity. $J$ Intern Med. (2017) 282:187-201. doi: 10.1111/joim.12632

112. Stanhope KL, Medici V, Bremer AA, Lee V, Lam HD, Nunez MV, et al. A dose-response study of consuming high-fructose corn syrupsweetened beverages on lipid/lipoprotein risk factors for cardiovascular disease in young adults. Am J Clin Nutr. (2015) 101:1144-54. doi: 10.3945/ajcn.114.100461

113. Taskinen MR, Packard CJ, Boren J. Dietary fructose and the metabolic syndrome. Nutrients. (2019) 11:1987. doi: 10.3390/nu11091987

114. Schwarz JM, Noworolski SM, Erkin-Cakmak A, Korn NJ, Wen MJ, Tai VW, et al. Effects of dietary fructose restriction on liver fat, de novo lipogenesis, and insulin kinetics in children with obesity. Gastroenterology. (2017) 153:743-52. doi: 10.1053/j.gastro.2017.05.043

115. Mardinoglu A, Wu H, Bjornson E, Zhang C, Hakkarainen A, Rasanen $\mathrm{SM}$, et al. An integrated understanding of the rapid metabolic benefits of a carbohydrate-restricted diet on hepatic steatosis in humans. Cell Metab. (2018) 27:559-71 e5. doi: 10.1016/j.cmet.2018.01.005

116. Hieronimus B, Griffen SC, Keim NL, Bremer AA, Berglund L, Nakajima K, et al. Effects of fructose or glucose on circulating ApoCIII and triglyceride 
and cholesterol content of lipoprotein subfractions in humans. J Clin Med. (2019) 8:913. doi: 10.3390/jcm8070913

117. Hieronimus B, Stanhope KL. Dietary fructose and dyslipidemia: new mechanisms involving apolipoprotein CIII. Curr Opin Lipidol. (2020) 31:206. doi: 10.1097/MOL.0000000000000653

118. Adiels M, Boren J, Caslake MJ, Stewart P, Soro A, Westerbacka J, et al. Overproduction of VLDL1 driven by hyperglycemia is a dominant feature of diabetic dyslipidemia. Arterioscler Thromb Vasc Biol. (2005) 25:1697-703. doi: 10.1161/01.ATV.0000172689.53992.25

119. Adiels M, Taskinen MR, Packard C, Caslake MJ, Soro-Paavonen A, Westerbacka J, et al. Overproduction of large VLDL particles is driven by increased liver fat content in man. Diabetologia. (2006) 49:755-65. doi: 10.1007/s00125-005-0125-z

120. Adiels M, Taskinen MR, Boren J. Fatty liver, insulin resistance, and dyslipidemia. Curr Diab Rep. (2008) 8:60-4. doi: 10.1007/s11892-008-0011-4

121. Chapman MJ, Ginsberg HN, Amarenco P, Andreotti F, Boren J, Catapano AL, et al. Triglyceride-rich lipoproteins and high-density lipoprotein cholesterol in patients at high risk of cardiovascular disease: evidence and guidance for management. Eur Heart J. (2011) 32:1345-61. doi: 10.1016/S1567-5688(11)70033-2

122. Mardinoglu A, Uhlen M, Boren J. Broad views of non-alcoholic fatty liver disease. Cell Syst. (2018) 6:7-9. doi: 10.1016/j.cels.2018.01.004

123. Faghihnia N, Mangravite LM, Chiu S, Bergeron N, Krauss RM. Effects of dietary saturated fat on LDL subclasses and apolipoprotein CIII in men. Eur J Clin Nutr. (2012) 66:1229-33. doi: 10.1038/ejen.2012.118

124. Sahebkar A, Simental-Mendia LE, Mikhailidis DP, Pirro M, Banach $M$, Sirtori CR, et al. Effect of omega-3 supplements on plasma apolipoprotein C-III concentrations: a systematic review and metaanalysis of randomized controlled trials. Ann Med. (2018) 50:565-75. doi: $10.1080 / 07853890.2018 .1511919$

125. Morton AM, Furtado JD, Lee J, Amerine W, Davidson MH, Sacks FM. The effect of omega- 3 carboxylic acids on apolipoprotein CIII-containing lipoproteins in severe hypertriglyceridemia. J Clin Lipidol. (2016) 10:1442-51 e4. doi: 10.1016/j.jacl.2016.09.005

126. Oscarsson J, Hurt-Camejo E. Omega-3 fatty acids eicosapentaenoic acid and docosahexaenoic acid and their mechanisms of action on apolipoprotein B-containing lipoproteins in humans: a review. Lipids Health Dis. (2017) 16:149. doi: 10.1186/s12944-017-0541-3

127. Ito Y, Azrolan N, O'Connell A, Walsh A, Breslow JL. Hypertriglyceridemia as a result of human apo CIII gene expression in transgenic mice. Science. (1990) 249:790-3. doi: 10.1126/science.2167514

128. Reyes-Soffer G, Ngai CI, Lovato L, Karmally W, Ramakrishnan R, Holleran $S$, et al. Effect of combination therapy with fenofibrate and simvastatin on postprandial lipemia in the ACCORD lipid trial. Diabetes Care. (2013) 36:422-8. doi: $10.2337 / \mathrm{dc} 11-2556$

129. Attia N, Durlach V, Cambilleau M, Roche D, Girard-Globa A. Postprandial concentrations and distribution of apo C-III in type 2 diabetic patients. Effect Of bezafibrate treatment. Atherosclerosis. (2000) 149:427-33. doi: 10.1016/S0021-9150(99)00337-8

130. Lemieux I, Salomon H, Despres JP. Contribution of apo CIII reduction to the greater effect of 12-week micronized fenofibrate than atorvastatin therapy on triglyceride levels and LDL size in dyslipidemic patients. Ann Med. (2003) 35:442-8. doi: 10.1080/07853890310011969

131. de Man FH, de Beer F, van der Laarse A, Jansen H, Leuven JA, Souverijn $\mathrm{JH}$, et al. The hypolipidemic action of bezafibrate therapy in hypertriglyceridemia is mediated by upregulation of lipoprotein lipase: no effects on VLDL substrate affinity to lipolysis or LDL receptor binding. Atherosclerosis. (2000) 153:363-71. doi: 10.1016/S0021-9150(00)00409-3

132. Wagner JA, Larson PJ, Weiss S, Miller JL, Doebber TW, Wu MS, et al. Individual and combined effects of peroxisome proliferator-activated receptor and \{gamma\} agonists, fenofibrate and rosiglitazone, on biomarkers of lipid and glucose metabolism in healthy nondiabetic volunteers. J Clin Pharmacol. (2005) 45:504-13. doi: 10.1177/0091270004273136

133. Hernandez C, Molusky M, Li Y, Li S, Lin JD. Regulation of hepatic ApoC3 expression by PGC-1beta mediates hypolipidemic effect of nicotinic acid. Cell Metab. (2010) 12:411-9. doi: 10.1016/j.cmet.2010.09.001

134. Sahebkar A, Simental-Mendia LE, Mikhailidis DP, Pirro M, Banach $\mathrm{M}$, Sirtori CR, et al. Effect of statin therapy on plasma apolipoprotein
CIII concentrations: a systematic review and meta-analysis of randomized controlled trials. J Clin Lipidol. (2018) 12:801-9. doi: 10.1016/j.jacl.2018.01.008

135. Maki KC, Bays HE, Dicklin MR, Johnson SL, Shabbout M. Effects of prescription omega-3-acid ethyl esters, coadministered with atorvastatin, on circulating levels of lipoprotein particles, apolipoprotein CIII, and lipoprotein-associated phospholipase A2 mass in men and women with mixed dyslipidemia. J Clin Lipidol. (2011) 5:483-92. doi: 10.1016/j.jacl.2011.09.001

136. Dunbar RL, Nicholls SJ, Maki KC, Roth EM, Orloff DG, Curcio D, et al. Effects of omega-3 carboxylic acids on lipoprotein particles and other cardiovascular risk markers in high-risk statin-treated patients with residual hypertriglyceridemia: a randomized, controlled, doubleblind trial. Lipids Health Dis. (2015) 14:98. doi: 10.1186/s12944-0150100-8

137. Gouni-Berthold I. The role of antisense oligonucleotide therapy against apolipoprotein-CIII in hypertriglyceridemia. Atheroscler Suppl. (2017) 30:19-27. doi: 10.1016/j.atherosclerosissup.2017.05.003

138. Watts JK, Corey DR. Silencing disease genes in the laboratory and the clinic. J Pathol. (2012) 226:365-79. doi: 10.1002/path.2993

139. Crooke ST, Witztum JL, Bennett CF, Baker BF. RNA-Targeted therapeutics. Cell Metab. (2018) 27:714-39. doi: 10.1016/j.cmet.2018.03.004

140. Springer AD, Dowdy SF. GalNAc-siRNA conjugates: leading the way for delivery of RNAi therapeutics. Nucleic Acid Ther. (2018) 28:109-18. doi: $10.1089 /$ nat.2018.0736

141. Makinen P, Ruotsalainen AK, Yla-Herttuala S. Nucleic acid-based therapies for atherosclerosis. Curr Atheroscler Rep. (2020) 22:10. doi: $10.1007 / \mathrm{s} 11883-020-0826-2$

142. Gaudet D, Alexander VJ, Baker BF, Brisson D, Tremblay K, Singleton $\mathrm{W}$, et al. Antisense inhibition of apolipoprotein C-III in patients with hypertriglyceridemia. $N$ Engl $J$ Med. (2015) 373:438-47. doi: 10.1056/NEJMoa1400283

143. Gelrud A, Digenio A, Alexander V, Williams K, Hsieh A, GouniBerthold I, et al. Treatment with Volanesorsen (VLN) reduced triglycerides and pancreatitis in patients with FCS and sHTG vs placebo: results of the APPROACH and COMPASS. J Clin Lipidol. (2018) 12:537. doi: 10.1016/j.jacl.2018.03.032

144. Digenio A, Dunbar RL, Alexander VJ, Hompesch M, Morrow L, Lee RG, et al. Antisense-mediated lowering of plasma apolipoprotein C-III by volanesorsen improves dyslipidemia and insulin sensitivity in type 2 diabetes. Diabetes Care. (2016) 39:1408-15. doi: 10.2337/dc16-0126

145. Alexander VJ, Xia S, Hurh E, Hughes SG, O'Dea L, Geary RS, et al. $\mathrm{N}$-acetyl galactosamine-conjugated antisense drug to APOC3 mRNA, triglycerides and atherogenic lipoprotein levels. Eur Heart J. (2019) 40:278596. doi: 10.1093/eurhearti/ehz209

146. Wolska A, Lo L, Sviridov DO, Pourmousa M, Pryor M, Ghosh SS, et al. A dual apolipoprotein C-II mimetic-apolipoprotein C-III antagonist peptide lowers plasma triglycerides. Sci Transl Med. (2020) 12:eaaw7905. doi: 10.1126/scitranslmed.aaw7905

147. Huynh K. Dual apoC-II mimetic and apoC-III antagonist for hypertriglyceridaemia. Nat Rev Cardiol. (2020) 17:201. doi: 10.1038/s41569-020-0351-6

148. Reeskamp LF, Tromp TR, Stroes ESG. The next generation of triglyceridelowering drugs: will reducing apolipoprotein C-III or angiopoietin like protein 3 reduce cardiovascular disease? Curr Opin Lipidol. (2020) 31:140-6. doi: 10.1097/MOL.0000000000000679

Conflict of Interest: The authors declare that the research was conducted in the absence of any commercial or financial relationships that could be construed as a potential conflict of interest.

Copyright (๑) 2020 Borén, Packard and Taskinen. This is an open-access article distributed under the terms of the Creative Commons Attribution License (CC BY). The use, distribution or reproduction in other forums is permitted, provided the original author(s) and the copyright owner(s) are credited and that the original publication in this journal is cited, in accordance with accepted academic practice. No use, distribution or reproduction is permitted which does not comply with these terms. 